\title{
Corrosion Inhibition of Titanium in Hydrochloric Acid containing $\mathrm{Na}_{2} \mathrm{MoO}_{4}$
}

\author{
Junying $\mathrm{Hu}^{*}$, Longjun Chen, Xiankang Zhong, Siyu Yu, Zhi Zhang, Dezhi Zeng, Taihe Shi
}

State Key Laboratory of Oil and Gas Reservoir Geology and Exploitation, School of Oil and Natural Gas Engineering, Southwest Petroleum University, Chengdu 610500, China

*E-mail: hujunying01@yeah.net

doi: $10.20964 / 2017.10 .16$

Received: 27 May 2017 / Accepted: 19 July 2017 / Published: 12 September 2017

The corrosion inhibition behaviors and mechanisms of $\mathrm{Na}_{2} \mathrm{MoO}_{4}$ for $\mathrm{Ti}$ in $15 \mathrm{wt} \% \mathrm{HCl}$-acidizing fluid used in natural gas exploitation were studied via potentiodynamic polarization, electrochemical impedance spectroscopy (EIS) and Mott-Schottky techniques. The results show that the $\mathrm{MoO}_{4}{ }^{2-}$ plays a significant role in the formation and stability of the passive film on Ti surface. As the concentration of $\mathrm{MoO}_{4}{ }^{2-}$ increases to $0.01 \mathrm{wt} \%$, the hydrogen evolution reaction (cathodic process) is apparently inhibited, and the anode process changes from active-passivation state to passivation state.

Keywords: Corrosion; Acidizing fluid; $\mathrm{Ti} ; \mathrm{Na}_{2} \mathrm{MoO}_{4}$

\section{$\underline{\text { FULL TEXT }}$}

(C) 2017 The Authors. Published by ESG (www.electrochemsci.org). This article is an open access article distributed under the terms and conditions of the Creative Commons Attribution license (http://creativecommons.org/licenses/by/4.0/). 